\title{
Acceptance of disease and lifestyle modification after diagnosis among young adults with epilepsy
}

\author{
This article was published in the following Dove Press journal: \\ Patient Preference and Adherence \\ 31 January 2017 \\ Number of times this article has been viewed
}

\author{
Anna Staniszewska' \\ Urszula Religioni² \\ Marta Dąbrowska-Bender ${ }^{3}$ \\ 'Department of Experimental and \\ Clinical Pharmacology, Medical \\ University of Warsaw, ${ }^{2}$ Collegium \\ of Socio-Economics, Warsaw School \\ of Economics, ${ }^{3}$ Department of Public \\ Health, Medical University of Warsaw, \\ Warsaw, Poland
}

Aim: Assessment of factors affecting the degree of illness acceptance in patients with epilepsy and determination of whether the diagnosis of epilepsy influenced the functioning of this population group.

Materials and methods: The Acceptance of Illness Scale (AIS) and authors' own questionnaire were used in this study. The study included 264 patients with epilepsy aged 20-40 years. The study was carried out during the period from June 2015 to June 2016. Participants were recruited through multiple channels, including online websites, a forum for people suffering from epilepsy, and from a neurological outpatient clinic in Warsaw.

Results: The mean value for overall rates of illness acceptance for all patients was $25.05 \pm 5.23$, which indicated a mean level of illness acceptance of the patients. A significant correlation was observed between the results on AIS and the marital status of patients $(P=0.04541)$. However, statistical analysis did not support the significant association between the illness acceptance and other socio-demographic factors and clinical aspects ( $P>0.05$ in all cases). An analysis of the correlation between the level of illness acceptance and taking life decisions by the patients showed that the only statistically significant difference was the influence of an illness on the decision about marriage ( $P=0.032383)$.

Conclusion: The problem of illness acceptance is often addressed in scientific research. It seems to be difficult to attain the state of full illness acceptance, especially in a situation when a number of changes have to be made in a patient's current life and everyday functioning. It can be argued that illness acceptance has a positive meaning because it entails benefits resulting from better mental and physical comfort of a patient. The time needed for the attainment of full illness acceptance is individual for every patient and also depends on many factors.

Keywords: epilepsy, acceptance of illness, lifestyle, young adults, AIS

\section{Introduction}

It can be argued that a disease usually occurs suddenly and unexpectedly, and a chronic disease makes patients change their outlook on life, reevaluate their life and change priorities. Once a diagnosis is made, a patient might experience a variety of reactions, and some of them might be difficult to predict. There are patients who accept a diagnosis with humility. They accept the disease and pick the fight for normal functioning. Others cannot come to terms with this new and difficult situation.

Patients suffering from epilepsy are ashamed of their illness and usually hide the fact about it. The reason might be that in Polish society there are still many myths about this disease and those who suffer from it. ${ }^{1}$ Epilepsy is a heterogeneous disease that is characterized by recurrent epileptic seizures. Seizures might take different forms, ranging from seizures that are practically unnoticeable to the patient and their environment (the so-called absence seizures) to seizures that are difficult
Correspondence: Anna Staniszewska Department of Experimental and Clinical Pharmacology, Medical University of Warsaw, Banacha Ib Street, 02-067

Warsaw, Poland

$\mathrm{Tel} / \mathrm{fax}+48221166160$

Email anna.staniszewska@wum.edu.pl 
to manage, such as tonic-clonic seizures. Furthermore, seizures might occur at any time of day or night and with a different frequency. Patients suffering from epilepsy experience anxiety connected with finding/keeping a job, ${ }^{2}$ having children, ${ }^{3}$ having an active driving license, social life ${ }^{4,5}$ and other aspects of life. All these factors influence the level of accepting the illness by epileptics, as well as their perception of quality of life. ${ }^{6}$

\section{Aim}

The aim of the study was to assess the level of illness acceptance in young adults diagnosed with epilepsy and to determine whether the diagnosis of epilepsy influenced the functioning of this population group.

\section{Materials and methods}

The study was conducted using a diagnostic survey method and the authors' own questionnaire. The questionnaire included 4 questions concerning demographic information, 5 questions referring to patients' clinical status, 10 questions regarding changes in lifestyle after epilepsy was diagnosed and 8 questions concerning the influence of epilepsy diagnosis on particular aspects of patients' functioning. Most questions included in the survey were taken from surveys that were used in other studies related to the topic, or they were based on available scientific literature. In part, results showed all the possible answers with the authors' questionnaire. Another tool that was used in the study was Acceptance of Illness Scale (AIS). ${ }^{7}$ AIS was developed in the US by Felton BJ, Revenson TA and Hinrichsen GA in 1984, whereas in Poland, it was adapted by Juczyński Z. It enables researchers to assess patients' acceptance level for any disease. The scale consists of 8 statements describing the negative consequences of poor health. The respondents' answers are scored 1-5 as follows: 1 - strongly agree, 2 - agree, 3 - don't know, 4 disagree, and 5 - strongly disagree. The total score, between 8 and 40 points, is a measure of illness acceptance. The higher the level, the better the illness adaptation and the lower the sense of mental discomfort of a patient. Scores below 20 points are considered low and indicate no or poor acceptance of and adaptation to an illness, as well as significant emotional problems related to it. Scores between 20 and 30 points indicate a moderate level of acceptance. Scores above 30 points indicate high or full acceptance of one's condition.

The study was carried out during the period from June 2015 to June 2016. Participants were recruited through multiple channels, including online websites, a forum for people suffering from epilepsy, and from a neurological outpatient clinic in Warsaw. Patients were informed about the aim of the study, and they were instructed how to complete the questionnaires. Participation in the survey was voluntary and anonymous. Completion of survey was deemed to be agreement of consent from the participants. The inclusion criteria were as follows: patients with epilepsy, consent to participate in the study, lack of comorbidities and literacy. The target group consisted of young adults. The period of the so-called young adulthood can be defined in many ways. From the psychological angle, this term refers to people aged 20/30-35/40 years, ${ }^{8}$ whereas from the perspective of biology, it refers to people aged 18/20-30/35 years. ${ }^{9}$ The study group in this research was composed of persons aged 20-40 years. The study was narrowed to this age group because young adults constitute a population group whose vision about the future, both personal and professional, has more often than not already been shaped, and the diagnosis of a chronic illness - epilepsy in this case - might have a significant influence on their further choices. Results from 300 persons were obtained, and the final analysis included data from 264 patients (26 persons did not respond to all questions, 8 persons were diagnosed not only with epilepsy but also with other diseases and 2 persons did not fulfill the age criterion). Variables were described using descriptive statistics (arithmetic average, minimum, maximum and standard deviation [SD]) and distribution of variables. The single-factor analysis of variance (ANOVA) and Kruskal-Wallis test were used for the purpose of statistical analysis of the results of variance between the study groups. The nonparametric Mann-Whitney $U$ test was employed for the comparison of differences between the 2 study groups. Statistically significant values were $P$-values $<0.05$. The project was approved by the Ethics Committee, Medical University of Warsaw (ref no AKBE/159/16).

The Cronbach's $\alpha$ coefficient for the internal consistency reliability of the AIS, carried out while adapting questionnaires to the Polish environment, amounted to $0.85 .^{7}$

\section{Results}

\section{Socio-demographic characteristics of patients}

Data analysis demonstrated that women constituted a slightly predominant group in the examined group (58.7\%). Patients' mean age was $28.9 \pm 5.8$ years. Most of them had vocational education $(\mathrm{N}=119,45.1 \%)$ and were not married $(\mathrm{N}=96,36.3 \%)$. The mean duration of epilepsy was $149.9 \pm 112.1$ months. Large majority of the patients $(\mathrm{N}=92$; $34.8 \%$ ) suffered from only one type of seizure (primarily generalized). Regarding pharmacotherapy, more than half 
of the patients $(\mathrm{N}=152,57.6 \%)$ were on a monotherapy and nearly a half of the participants $(\mathrm{N}=127 ; 48.1 \%)$ were on a therapy using old-generation antiepileptic drugs (AEDs). Regarding the frequency of taking medications, majority of the patients $(\mathrm{N}=188 ; 71.2 \%)$ were taking $\geq 2$ medications daily. Table 1 presents the socio-demographic characteristics of the patient population.

\section{The level of illness acceptance (AIS)}

The rate of illness acceptance in those surveyed suffering from epilepsy amounted to 25.05 ( $\mathrm{SD}=5.23$ ), which could be referred to as a medium level. Majority of the studied group (70.1\%) showed a medium level of illness acceptance, and the most frequent result on the AIS was 27.00. A total of $16.3 \%$ of the patients showed a low level of illness acceptance, and $13.6 \%$ showed a high level thereof. In the studied group, no

Table I Characteristics of the examined group with epilepsy

\begin{tabular}{|c|c|c|}
\hline & $\mathbf{N}$ & $\%$ \\
\hline \multicolumn{3}{|l|}{ Demographic characteristics } \\
\hline \multirow[t]{2}{*}{ Age } & \multicolumn{2}{|c|}{ Mean $=28.9 \pm 5.8$ years } \\
\hline & \multicolumn{2}{|c|}{ Range: $20-40$ years } \\
\hline \multicolumn{3}{|l|}{ Sex } \\
\hline Female & 155 & 58.7 \\
\hline Male & 109 & 41.3 \\
\hline \multicolumn{3}{|l|}{ Education } \\
\hline Primary & 13 & 4.9 \\
\hline Vocational & 119 & 45.1 \\
\hline Secondary & 75 & 28.4 \\
\hline University & 57 & 21.6 \\
\hline \multicolumn{3}{|l|}{ Marital status } \\
\hline Single & 96 & 36.3 \\
\hline Married & 58 & 22.0 \\
\hline Widowed & 52 & 19.7 \\
\hline Divorced & 58 & 22.0 \\
\hline \multicolumn{3}{|l|}{ Clinical characteristics } \\
\hline \multirow[t]{2}{*}{ Duration of epilepsy } & \multicolumn{2}{|c|}{ Mean $=|49.9 \pm| \mid 12.1$ months } \\
\hline & \multicolumn{2}{|c|}{ Range: $2-468$ months } \\
\hline \multicolumn{3}{|l|}{ Type of seizure } \\
\hline Primarily generalized & 92 & 34.8 \\
\hline Partial & 49 & 18.6 \\
\hline Secondarily generalized & 88 & 33.3 \\
\hline Secondarily generalized + partial & 35 & 13.3 \\
\hline \multicolumn{3}{|l|}{ Medication } \\
\hline Monotherapy & 152 & 57.6 \\
\hline Polytherapy & 112 & 42.4 \\
\hline \multicolumn{3}{|l|}{ Kind of AEDs } \\
\hline Old generation & 127 & 48.1 \\
\hline New generation & 70 & 26.5 \\
\hline Old + new generation & 67 & 25.4 \\
\hline \multicolumn{3}{|l|}{ Dosage of AEDs } \\
\hline Once a day & 76 & 28.8 \\
\hline$\geq$ Twice a day & 188 & 71.2 \\
\hline
\end{tabular}

Abbreviation: AEDs, antiepileptic drugs. patient obtained the highest result, which is 40 points. Average values for particular statements, in accordance with AIS, ranged from 2.40 to 3.62 (mean 2.85). It was found that the biggest problem for the patients surveyed was to adjust to restrictions imposed on them by the illness (average 2.40), whereas being dependent on other people more than a patient would wish for it seemed to be the least significant issue (average 3.62). Detailed results in accordance with AIS are presented in Tables 2-4.

\section{The impact of epilepsy diagnosis on lifestyle}

Diagnosis of epilepsy, which is a chronic disease, forced those surveyed to modify some of their behaviors related to lifestyle. A total of $90.2 \%$ of patients surveyed $(\mathrm{N}=238)$ stated that after hearing the diagnosis, they increased their care about health, and 75\% ( $=198)$ implemented first changes in their lifestyle. Epilepsy diagnosis resulted in the following: - $67.4 \%$ of those surveyed $(\mathrm{N}=178)$ stated that they read leaflets of prescription drugs;

- $45.1 \%(\mathrm{~N}=119)$ stated that they read leaflets of over the counter (OTC) drugs;

- $29.9 \%(\mathrm{~N}=79)$ reduced the consumption of alcohol;

- $25 \%(\mathrm{~N}=66)$ decided to quit smoking;

- $19.7 \%(\mathrm{~N}=52)$ completely resigned from competitive sports;

- $18.2 \%(\mathrm{~N}=48)$ decided to reduce watching television (TV) to the minimum;

- $16.3 \%(\mathrm{~N}=43)$ decided to shorten the time of working on a computer;

- $14.8 \%(\mathrm{~N}=39)$ decided to care more about regular sleep pattern.

Furthermore, diagnosis of epilepsy negatively influenced certain choices of the patients. Majority of patients $80.3 \%$ - believed that epilepsy had negatively influenced their decision about having children. Almost half of the group (45.1\%) claimed that epilepsy negatively influenced their life as a whole. Interestingly, physical activity seemed to be an area of life that was influenced by the illness to the smallest extent (11.7\%) (Table 5).

\section{Results of statistical analysis}

There was a significant correlation between the results on AIS and marital status of patients $(P=0.04541)$. The highest score, and therefore the highest level of illness acceptance, was obtained by unmarried persons (26.28) and the lowest by those widowed (23.70). However, statistical analysis did not prove a significant association between acceptance of 
Table 2 Results of AIS test in the examined group

\begin{tabular}{lllllllr}
\hline $\mathbf{N}$ & Mean & Median & Dominant & $\begin{array}{l}\text { Cardinality } \\
\text { of dominant }\end{array}$ & Minimum & Maximum & SD \\
\hline 204 & 25.05 & 26.00 & 27.00 & 20 & 12.00 & 39.00 & 5.23 \\
\hline
\end{tabular}

Abbreviations: AIS, Acceptance of Illness Scale; SD, standard deviation.

the illness and other socio-demographic factors: sex, age and level of education $(P>0.05)$.

Similarly, nonsignificant differences were found between acceptance of the illness and clinical aspects: duration of the disease; type of seizure and kind, dosage and generation of AEDs $(P>0.05$ in all cases $)$.

An analysis of the correlation between the level of illness acceptance and taking life decisions by the patients showed that the only statistically significant difference was the influence of an illness on the decision about marriage. A higher test result was reached by those patients who, after finding out about their illness, declared that epilepsy diagnosis did not negatively influence their decision about getting married (25.62 vs 23.88) ( $P=0.032383)$.

\section{Discussion}

Acceptance of an illness helps a patient live normally and perform various roles despite threats, restrictions and problems connected with health limitation and health loss. Available scientific literature points out that the higher the level of illness acceptance, the more optimistic the patients are, the more they trust doctors and believe in treatment and the more actively they participate in the treatment process. ${ }^{10-14}$

The average rate of illness acceptance in the studied group was $25.05 \pm 5.23$, which could be referred to as a medium level of illness acceptance. Although no studies into illness acceptance in patients with epilepsy have been conducted in Poland so far, in Polish scientific literature, there are many studies that focused on acceptance of other illnesses. ${ }^{15-41}$ It can be observed that the level of illness acceptance in authors' own study, where the target group are patients diagnosed with epilepsy, is at a comparable, medium level compared with the level of illness acceptance in Polish patients suffering from other neurological diseases/ailments. Other results showed

Table 3 The level of acceptance of the disease according to the scale of AIS

\begin{tabular}{llll}
\hline Level of illness acceptance & Score & N & $\%$ \\
\hline Low & $8-19$ & 43 & 16.3 \\
Medium & $20-30$ & 185 & 70.1 \\
High & $>30$ & 36 & 13.6 \\
\hline
\end{tabular}

Abbreviation: AIS, Acceptance of Illness Scale. that patients suffering from ataxia were the only patients who represented a distinctively lower level of acceptance than other patients with neurological deficits/diseases (Table 6). Taking into account other somatic diseases, patients who represented the lowest acceptance of their illness were those who were suffering from chronic obstructive pulmonary disease ( $\mathrm{N}=96)$. Their results were as low as 19.00 points. Outpatients suffering from varicose veins $(\mathrm{N}=50)$ accepted their ailments to the greatest extent, which can be proved by a very high result on AIS, amounting to 37.02 points. Nonetheless, it should be stressed that the groups that were compared differed in size and that the population chosen for this study by the authors was the biggest $(\mathrm{N}=264)$.

Besides defining the level of illness acceptance, the aim of this study was also to determine whether socio-demographic variables influence the level of illness acceptance.

The first variable that was taken into account was the age of patients. Data analysis did not show an important correlation between the level of illness acceptance and the age of patients $(P>0.005)$. Similarly, Polish researchers from Torun who conducted an analysis in women treated for pathological changes of the cervix, ${ }^{23}$ as well as a research group from Rzeszów examining women after mastectomy, ${ }^{42}$ did not observe such a correlation.

An analysis conducted by the authors of this study did not prove a statistically significant correlation between patients' sex and the level of illness acceptance $(P>0.005)$. However, a different correlation was found in the studies conducted in the patients of surgery wards. According to those studies, men experienced lower psychological discomfort because of an illness, ${ }^{43}$ and in the case of patients suffering from ataxia, women found it more difficult to accept an illness. ${ }^{26}$

An analysis of authors' own data did not show a significant correlation between illness acceptance and education of respondents $(P>0.005)$. Similarly, Kaźmierczak et al, ${ }^{23}$ who studied illness acceptance in women treated for pathological changes of the cervix, and Pawlik et al, ${ }^{42}$ who examined the acceptance of cancer in women after mastectomy, did not prove the influence of education on illness acceptance. However, negative level of illness acceptance in persons with lower education was obtained by Niedzielski et $\mathrm{al},{ }^{44}$ who assessed the level of illness acceptance in selected chronic 
Table 4 Values obtained from individual claims on a scale of AIS in the examined group

\begin{tabular}{|c|c|c|c|c|}
\hline AIS & Mean & SD & Min & Max \\
\hline l've got problems to adjust to the limitations imposed by the disease & 2.40 & 1.4 & 1 & 5 \\
\hline Because of my health condition I'm not able to do what I like the most & 3.44 & 1.4 & I & 5 \\
\hline Sometimes illness makes me feel not needed & 3.27 & 1.4 & 1 & 5 \\
\hline Health problems make me more dependent on others than I want & 3.62 & 1.3 & I & 5 \\
\hline Illness makes me a burden to my family and friends & 3.33 & 1.5 & I & 5 \\
\hline Illness makes me a burden to my family and friends & 2.91 & 1.4 & I & 5 \\
\hline I'll never be self-sufficient enough to the level I would like to be & 3.19 & 1.4 & I & 5 \\
\hline I think people that spend time with me very often feel embarrassed because of my illness & 2.90 & 1.6 & I & 5 \\
\hline
\end{tabular}

Abbreviations: AIS, Acceptance of Illness Scale; SD, standard deviation; Min, minimum; Max, maximum.

diseases, Lelonek et $\mathrm{al},{ }^{43}$ who assessed the level of illness acceptance in patients of surgery wards, and Szafraniec et al, ${ }^{16}$ who studied illness acceptance in patients with rheumatoid arthritis. According to the authors of this article, people with higher education are characterized by higher awareness of risks associated with the noncompliance with medical recommendations, and thus, they are more willing to learn how to cope with an illness, which results in higher illness acceptance.

Authors' own study showed that among socio-demographic variables, only marital status was statistically significant for the level of illness acceptance $(P=0.04541)$. Persons who were not married were characterized by the higher level of illness acceptance, whereas patients whose spouses had died showed the lowest level of illness acceptance (26.28 vs 23.70 ). Explanation for this correlation can be based on the fact that unmarried women/unmarried men had to cope with the illness on their own from the time of the illness diagnosis to the time of their participation in the study, and therefore they could get used to their illness to some extent. Although it might have been easier for the widowed patients to cope with the consequences of their illness when their partners were alive and supported them in overcoming problems and adjusting to certain limitations connected with the illness, after the death of their spouses those patients could rely only on themselves.

Table 5 The impact of the diagnosis of epilepsy on selected aspects of the functioning patients

\begin{tabular}{llll}
\hline The diagnosis of epilepsy negatively & Yes & & No \\
impacted on & $\mathbf{N}(\%)$ & & $\mathbf{N}(\%)$ \\
\hline Decision about marriage & $86(32.6)$ & & $178(67.4)$ \\
Sexual activity & $34(12.9)$ & & $230(87.1)$ \\
Decision about driving license & $167(63.3)$ & $97(36.7)$ \\
Decision about choice/change profession & $123(46.6)$ & & $141(53.4)$ \\
Decision about own progeny & $212(80.3)$ & $52(19.7)$ \\
Physical activity & $31(11.7)$ & & $233(88.3)$ \\
Personal contact & $36(13.6)$ & $228(86.4)$ \\
All my life & $119(45.1)$ & $145(54.9)$ \\
\hline
\end{tabular}

With reference to the correlation between the marital status and the level of illness acceptance, it might be concluded that the results of other studies are inconsistent. The study by Moczydłowska et al ${ }^{45}$ conducted in patients of noninvasive treatment wards and surgery wards proved that the majority of patients with high illness acceptance at the level of 30-40 points on AIS were married. Another study by Łuczyk et al ${ }^{24}$ performed in a group of patients diagnosed with unstable angina pectoris showed that respondents who were married accepted their illness to a greater extent than patients who were single or widowed $(P<0.0001)$. Furthermore, a study by Kaźmierczak et $\mathrm{a}^{23}$ that examined a group of women treated for pathological changes of the cervix did not confirm a statistically important difference in the results on AIS with regard to the marital status of the studied sample of women. Nevertheless, a study by Lelonek and Kaczmarczyk ${ }^{43}$ confirmed the result obtained by the authors of this paper - patients who are single (unmarried man/unmarried women) show the highest level of illness acceptance.

A study by Czyźewska et al ${ }^{46}$ conducted among patients with epilepsy has also demonstrated a relation between the level of social support and the acceptance of illness; however, these aspects were not considered in the authors' study.

The next stage in the study was to determine the relation between the level of illness acceptance and medical factors. Epilepsy is an illness that has a significant influence on patients' lives due to its chronic character, various forms of seizures and frequency of their occurrence. Nevertheless, no correlation between the level of illness acceptance and medical factors was observed in this study (duration of disease; type of seizure; kind, dosage and generation of AEDs $[P>0.05$ in all cases $]$ ).

Disease duration had no significant influence on the level of illness acceptance, also in patients suffering from ataxia. ${ }^{26}$ A study in a group of patients diagnosed with myasthenia gravis conducted by Bilińska and Sitek $^{29}$ did not show a 
Table 6 The degree of acceptance of different diseases among Polish patients according to the scale AIS

\begin{tabular}{|c|c|c|c|}
\hline Classification of disease & Disease/symptom & $\mathbf{N}$ & Mean \\
\hline \multirow[t]{4}{*}{ Bone and joint diseases } & People after a total hip replacement ${ }^{15}$ & 98 & 23.65 \\
\hline & Rheumatoid arthritis $^{16}$ & 40 & 26.45 \\
\hline & Osteoporosis ${ }^{17}$ & 137 & 27.30 \\
\hline & Lumbar disk herniations $^{18}$ & 93 & 30.87 \\
\hline \multirow[t]{8}{*}{ Cancer diseases } & Cancer disease ${ }^{19}$ & 79 & 19.15 \\
\hline & Lung $^{20}$ & 243 & 23.17 \\
\hline & Leukemia $^{21}$ & 110 & 23.27 \\
\hline & Cancer disease ${ }^{22}$ & 100 & 25.35 \\
\hline & Colon/rectum ${ }^{20}$ & 238 & 27.74 \\
\hline & Breast $^{20}$ & 193 & 28.46 \\
\hline & Lesions of the cervix ${ }^{23}$ & 50 & 28.76 \\
\hline & Prostate $^{20}$ & 228 & 30.39 \\
\hline \multirow[t]{4}{*}{ Cardiovascular diseases } & Unstable angina $^{24}$ & 200 & 21.52 \\
\hline & Men after myocardial infarction ${ }^{7}$ & 42 & 22.14 \\
\hline & Varicose vein, surgically treated ${ }^{25}$ & 50 & 27.00 \\
\hline & Varicose vein, outpatients ${ }^{25}$ & 50 & 37.02 \\
\hline \multirow[t]{7}{*}{ Neurological diseases } & Ataxia $^{26}$ & 26 & 19.15 \\
\hline & Disability after stroke ${ }^{27}$ & 74 & 21.54 \\
\hline & Women diagnosed with migraine ${ }^{7}$ & 30 & 24.23 \\
\hline & Multiple sclerosis ${ }^{7}$ & 44 & 24.59 \\
\hline & Multiple sclerosis ${ }^{28}$ & 38 & 25.08 \\
\hline & Epilepsy (our study) & 264 & 25.05 \\
\hline & Myasthenia gravis ${ }^{29}$ & 32 & 25.87 \\
\hline \multirow[t]{6}{*}{ Metabolic diseases } & Diabetes, treated insulin and hemodialysis ${ }^{30}$ & 52 & 21.21 \\
\hline & Diabetes type $2^{31}$ & 77 & 25.16 \\
\hline & Diabetic neuropathy ${ }^{32}$ & 22 & 26.60 \\
\hline & Graves-Basedow's disease ${ }^{33}$ & 59 & 28.48 \\
\hline & Diabetes, all types ${ }^{34}$ & 98 & 29.00 \\
\hline & Diabetes without neuropathy $y^{32}$ & 37 & 29.60 \\
\hline \multirow[t]{4}{*}{ Renal diseases } & Chronic kidney disease, treated hemodialysis ${ }^{35}$ & 100 & 22.76 \\
\hline & Chronic kidney disease, treated hemodialysis ${ }^{30}$ & 68 & 24.31 \\
\hline & Chronic kidney disease, treated hemodialysis ${ }^{36}$ & 94 & 24.82 \\
\hline & Dialysis patients ${ }^{37}$ & 40 & 25.68 \\
\hline \multirow[t]{3}{*}{ Respiratory system diseases } & Chronic obstructive pulmonary disease ${ }^{38}$ & 96 & 19.00 \\
\hline & Chronic obstructive pulmonary disease ${ }^{39}$ & 105 & 20.60 \\
\hline & Bronchial asthma ${ }^{40}$ & 140 & 29.40 \\
\hline \multirow[t]{2}{*}{ Skin disease } & Psoriasis, inpatients ${ }^{41}$ & 33 & 26.55 \\
\hline & Psoriasis, outpatients ${ }^{41}$ & 28 & 27.25 \\
\hline
\end{tabular}

Abbreviation: AIS, Acceptance of Illness Scale.

statistically significant relation between illness acceptance and other parameters of psychological functioning and indicators for clinical condition.

Awareness of the causes and consequences of the disease allows patients to modify their current health behaviors. It remains without a doubt that after a patient is diagnosed with epilepsy, they should pay attention to their lifestyle, since many factors may lower the seizure threshold. The aim of the second part of this study was to examine whether the epilepsy diagnosis influenced the functioning of patients and changes in their behavior.

The result obtained in this study can be referred to as optimistic because as many as $90.2 \%(\mathrm{~N}=238)$ of respondents started to take better care of their health after they were diagnosed with epilepsy and 75\% ( $=198)$ undertook first activities. Although authors' own study did not show a significant relation between the level of illness acceptance and the modification of current lifestyle $(P>0.005)$, the data that were obtained prove that the majority of patients were aware of the necessity of such a modification. In the study in patients diagnosed with primary open-angle glaucoma, Karna-Matyjaszek et $\mathrm{al}^{47}$ observed a statistically significant correlation between the level of illness acceptance and resignation from different forms of activities $(P=0.0005)$. The study also showed that the lower the level of illness acceptance, the higher the extent to which patients resigned from life activities. 
Regarding patients with ataxia, the greatest problem in accepting the illness resulted from patients' dependence on third parties and the feeling that they would never be selfsufficient to the extent to which they would like to be. The patients also felt that the disease limited them or precluded them from taking activities that had given them pleasure before the disease occurred. ${ }^{26}$

In our study, $18.2 \%$ of patients decided to reduce watching TV to the minimum and $16.3 \%$ decided to shorten the time of working on the computer after they were diagnosed with epilepsy.

It is recommended that patients whose electroechocardiogram (EEG) showed paroxysmal changes in response to photostimulation (PS) should limit working on the computer, watching TV and staring at the sun, as well as avoid exposure to strobe lights. ${ }^{48}$ Furthermore, patients with photosensitivity should watch TV on a screen that is not bigger than 21", use remote control and watch TV from an appropriate distance from the screen in a well-lit room where the light is directed on to the screen. ${ }^{49}$

Occurrence of the disease often requires changing interests and hobbies and reducing physical activity. The results of our study show that $19.7 \%$ of respondents totally resigned from extreme sports after being diagnosed with epilepsy. With regard to sport disciplines, patients suffering from epilepsy should resign from the so-called extreme sports, competitive sports and such sports in which even temporary loss of consciousness may lead to tragic consequences for the patient or the environment. Those sports include diving, climbing, skydiving and lonely swimming in an open space. However, a patient must not be prevented from doing sports at all, eg, tennis or table tennis, and every patient should be treated individually. It is also discouraged for the patients to take short intense effort, such as very fast running that causes deep breathing (as in hyperventilation attempt during EEG). When choosing a sport discipline, a patient should take into account the type of seizures and their frequency. If seizures are not well controlled, a patient should do sport in the company of other people and use protective measures, eg, helmet and protective gear when skating or cycling. ${ }^{48}$

An important element that influences the success of the therapy is patients' attitude to stimulants. In our study, $29.9 \%$ of respondents $(\mathrm{N}=79)$ reduced the consumption of alcohol after being diagnosed with epilepsy and $25 \%$ of subjects $(\mathrm{N}=66)$ decided to quit smoking. Scientific literature shows that correlation between alcohol and seizures/epilepsy is a complex issue. On the one hand, excessive consumption of alcohol is a risk factor for the occurrence of brain diseases or metabolic encephalopathy. On the other hand, ethanol toxicity affects neurotransmission and modifies epileptic threshold. The risk of seizures related to alcohol depends on the daily dose of alcohol consumption as well as on other factors, such as sex, age, genetic factors, environmental factors and concomitant diseases. Furthermore, excessive consumption of alcohol is a risk factor for the occurrence of epilepsy, and consumption of alcohol during the treatment might lead to its interaction with AEDs. ${ }^{50}$

Alcohol withdrawal is also a frequent cause for the occurrence of a seizure or status epilepticus. ${ }^{51-53}$ It appears that alcohol is a cause for the occurrence of epileptic seizures related to alcohol withdrawal or excessive consumption in $5 \%-10 \%$ of patients and alcoholism triples the risk of epileptic seizures. ${ }^{54}$

Some drugs might provoke seizures or lower seizure threshold in patients suffering from epilepsy (eg, high doses of penicillin, isoniazid, aminophylline, theophylline, tricyclic antidepressants, insulin and oral hypoglycemic drugs and antihistamines). Seizures might also be related to withdrawal of drugs (eg, benzodiazepines, barbiturates, other AEDs and opiates). ${ }^{54}$ Thus, knowledge about drugs that lower seizure threshold is of significant importance for patients and for the success of a therapeutic process. Information whether a particular preparation interacts with AEDs or affects seizure threshold is included in a drug information leaflet. In our study, $67.4 \%$ of respondents $(\mathrm{N}=178)$ admitted that they read information leaflets of prescription drugs and $45.1 \%$ $(\mathrm{N}=119)$ read information leaflets of OTC drugs. Although all drugs affecting seizures listed earlier are available in Poland on prescription only, and doctors are supposed to adequately choose drugs for patients who use AEDs, many patients suffering from epilepsy either do not inform doctors, other than a neurologist/epileptologist, of their illness and AEDs which they use or they use drugs upon their own discretion, eg, drugs from a previously prescribed therapy. Such incorrect and reckless practices might significantly affect the clinical condition of patients. ${ }^{55}$

Ineffective sleep and insufficient sleep also lower seizure threshold.$^{54}$ Therefore, it is important that patients take care of proper sleep. Unfortunately, only $14.8 \%$ of patients $(\mathrm{N}=39)$ participating in our study decided to take care of regular sleep after they were diagnosed with epilepsy.

Patients with epilepsy often reduce their social activity, which might result in a lower ratio of marriages in this group compared with the general population. ${ }^{56}$ It is worth referring to Polish results that constitute a part of an international 
program assessing the state of knowledge about epilepsy among patients $(\mathrm{N}=1,028)$ and their caregivers $(\mathrm{N}=1,033)$. This study shows that only $45 \%$ of the respondents were married and the remaining 55\% were single. According to half of the respondents, the disease had a substantial impact on their social life. About one-fourth of the respondents felt stigmatized and claimed that the environment treated them as persons of a worse category. ${ }^{57}$ A statistical analysis performed in our study showed that patients who declared that epilepsy diagnosis did not affect negatively their decision about getting married obtained a higher result on AIS (25.62 vs 23.88) ( $P=0.032383)$. Thus, it can be claimed that the attitude of epileptics to marriage improved.

Other factors having a negative effect on compliance are mood and anxiety disorders in chronic disease; however, these aspects were not considered in our study.

\section{Conclusion}

The problem of illness acceptance is often addressed in scientific research. It seems to be difficult to attain the state of full illness acceptance, especially in a situation when a number of changes have to be made in a patient's current life and everyday functioning. It can be argued that illness acceptance has a positive meaning because it entails benefits resulting from better mental and physical comfort of a patient. However, the time needed for the attainment of full illness acceptance is individual for every patient. The authors' own study and the results of studies mentioned earlier show that illness acceptance also depends on many factors.

\section{Disclosure}

The authors report no conflicts of interest in this work.

\section{References}

1. Fisher RS, Vickrey BG, Gibson P, et al. The impact of epilepsy from the patient's perspective, I: descriptions and subjective perceptions. Epilepsy Res. 2000;41:39-51.

2. Staniszewska A, Sobiecki M, Duda-Zalewska A, et al. Aktywność zawodowa chorych na padaczkę [Professional activity of people with epilepsy]. Med Pr. 2015;66(3):343-350. Polish.

3. Buczniewska P, Staniszewska A. Kobieta chora na padaczkę stojąca przed wyborem antykoncepcji [A woman suffering from epilepsy, facing the choice of contraception]. Położna Nauka i praktyka. 2011;2(14):32-38. Polish.

4. Staniszewska A, Kurkowska-Jastrzębska I, Tarchalska-Kryńska B. Codzienne problemy chorych na padaczkę [Everyday problems patients with epilepsy]. Med i pasje. 2011;1(11):14-17. Polish.

5. Staniszewska A, Tarchalska-Kryńska B. Czego obawiają się chorzy na padaczkę? [What do the patients with epilepsy afraid of?]. Problemy Terapii Monitorowanej. 2008;3(19):193-202. Polish.

6. Staniszewska A, Jastrzębska-Kurkowska I, Tarchalska-Kryńska B. Quality of life in patients with epilepsy in Poland. J Public Health Nurs Med Rescue. 2015;3:20-26.
7. Felton BJ, Revension TA, Hionrichsen GA (adaptation Juczyński Z). Skala akceptacji choroby AIS [Acceptance of Illness Scale AIS]. In: Juczyński Z, editor. Narzędzia pomiaru w promocji i psychoonkologii zdrowia. Warszawa: Pracownia Testów Psychologicznych; 2009:162-166. Polish.

8. Trempała J, Harwas-Napierała B, editors. Psychologia rozwoju czlowieka [Psychology of Human Development]. 2nd ed. Warszawa: Wydawnictwo Naukowe PWN; 2008. Polish.

9. Brzezińska AI, editor. Psychologiczne portrety człowieka [Psychological Portraits of Human]. Gdańsk: Gdańskie Wydawnictwo Psychologiczne; 2005. Polish.

10. Kossakowska M. Strategie radzenia sobie z chorobą przewlekłą w stwardnieniu rozsianym [Strategies of coping with chronic illness in patients with multiple sclerosis]. Post Psychiatr Neurol. 2008;17:15-21. Polish.

11. Motyka M. Psychoterapia elementarna $w$ opiece ogólnomedycznej [Psychotherapy Elementary in Medical Care]. 1st ed. Kraków: Wyd. Uniwersytetu Jagiellońskiego; 2002. Polish.

12. Karski JB. Praktyka i teoria promocji zdrowia [The Practice and Theory of Health Promotion]. 2nd ed. Warszawa: Wyd. CeDeWu; 2006. Polish.

13. Rostowska T, Walęcka-Matyja K. Obraz siebie i poziom samooceny kobiet po amputacji piersi oraz kobiet ze schorzeniami skóry - analiza porównawcza [The self-image and the level of self-appraisal of women after mastectomy and women with skin illnesses - comparative analysis]. Psychoonkol. 2003;7(1):7. Polish.

14. Oleś P, Steuden S, Toczołowski J. Jak świata mniej widzę: zaburzenia widzenia a jakość życia [How I See the World Less: Visual Disturbances and Quality of Life]. Lublin: Towarzystwo Naukowe Katolickiego Uniwersytetu Lubelskiego; 2002. Polish.

15. Kurowska K, Rumińska B. Akceptacja choroby i sposoby radzenia sobie ze stresem u osób po wszczepieniu endoprotezy stawu biodrowego [Disease acceptation and ways of coping with the emotional stress of people after a total hip replacement]. Pielęgniarstwo Chirurgiczne $i$ Angiologiczne. 2011;4:203-210. Polish.

16. Szafraniec R, Szczuka E, Pawłowska A. Akceptacja choroby przez pacjentów z reumatoidalnym zapaleniem stawów [Acceptance of illness in patients with rheumatoid arthritis]. Fizjoterapia Polska. 2012;1(12):39-48. Polish and English.

17. Pawlikowska-Łagód K, Janiszewski M, Firlej E, Dąbska O, Sak J. Akceptacja choroby kobiet leczących się z powodu osteoporozy [Acceptance of diseases of women treated for osteoporosis]. J Educ Health Sport. 2016;6(5):139-148. Polish.

18. Kocjan J. Poczucie koherencji i akceptacja choroby a nasilenie dolegliwości bólowych u osób z chorobą dyskową odcinka lędźwiowego kręgosłupa [Sense of coherence, acceptance of an illness and pain intensity in patients with lumbar disc herniations]. J Educ Health Sport. 2016;6(4):481-492. Polish.

19. Zielińska-Więczkowska H, Żychlińska E. Akceptacja choroby nowotworowej i jej związek z jakością życia osób starszych objętych opieką paliatywną stacjonarną i domową [Acceptance of cancer and its relationship with quality of life of older adults receiving institutional and home palliative care]. Med Rodz. 2015;4(18):51-156. Polish.

20. Religioni U, Czerw A, Deptałą A. Acceptance of cancer in patients diagnosed with lung, breast, colorectal and prostate carcinoma. Iran J Public Health. 2015;44(8):1135-1142.

21. Wiraszka G, Lelonek B. Funkcjonowanie chorego z białaczką a akceptacja choroby nowotworowej [The functioning of a patient with leukaemia and the acceptance of neoplastic disease]. Studia Med. 2008;10:21-26. Polish.

22. Kołpa M, Wywrot-Kozłowska B, Jurkiewicz B, Grochowska A. Czynniki determinujące akceptację i przystosowanie do choroby nowotworowej [The factors determining acceptance and adjustment to cancer]. Pielęgniarstwo Chirurgiczne i Angiologiczne. 2015;3:165-169. Polish.

23. Kaźmierczak M, Kubiak I, Gebuza G, Gierszewska M, Mieczkowska E. Czynniki determinujące akceptację choroby przez kobiety leczone $\mathrm{z}$ powodu zmian patologicznych szyjki macicy [Factors that determine the acceptance of illness in women who are treated for lesions of the cervix]. Medycyna Ogólna i Nauki o Zdrowiu. 2015;21(2):181-186. Polish. 
24. Łuczyk R, Juśko A, Łuczyk M, Krzyżanowska E, Plottke A. Akceptacja choroby w grupie pacjentów z rozpoznaną dusznicą bolesną niestabilną [Acceptance of the disease in patients with a diagnosis of unstable angina]. J Educ Health Sport. 2016;6(7):453-470. Polish.

25. Wiśniewska-Szumacher A, Karakiewicz B, Bażydło M, SzkupJabłońska M, Jurczak A, Grochans E. Czynniki determinujące akceptację choroby przez pacjentów leczonych z powodu żylaków kończyn dolnych [Factors determining the acceptance of the disease by patients treated for varicose veins]. Problemy Pielęgniarstwa 2013;21(4):489-495. Polish.

26. Kaźmierska-Zając M, Rosińczuk-Tonderys J. Stopień akceptacji choroby pacjentów cierpiących na ataksję [The Degree of Disease Acceptance by Patients with Ataxia]. 2016. Available from: http:// ataksja.home.pl/autoinstalator/wordpress/wp-content/uploads/2011/10/ stopien_akceptacji.pdf. Accessed September 30, 2016. Polish.

27. Kamusińska E, Rojowska A. Akceptacja niepełnosprawności przez osoby po przebytym udarze mózgu [Acceptance of disability for people after stroke]. Studia Med. 2012;25(1):37-42. Polish.

28. Pejas-Grzybek L, Agnieszka Skorupska-Król A. The degree of illness acceptance among patients with multiple sclerosis. J Neurol Neurosurg Nurs. 2015;4(1):19-23.

29. Bilińska MM, Sitek EJ. Jakość życia i akceptacja choroby w miastenii [Quality of life and acceptance of illness in patients with myasthenia gravis]. Adv Psychiatr Neurol. 2007;16:139-143. Polish.

30. Marzec A, Andruszkiewicz A, Banaszkiewicz M. Poczucie koherencji, akceptacja choroby a funkcjonowanie w chorobie przewlekłej osób chorych na chorobę nerek i chorych na cukrzycę, hemodializowanych doniesienia wstępne [The sense of coherence, the acceptance of illness and functioning in chronic illness in patients with chronic kidney disease and patients with diabetes, treated with hemodialysis - a preliminary study]. Pielegniarstwo XXI Wieku. 2011;2(35):51-56. Polish.

31. Kurowska K, Lach B. Akceptacja choroby i sposoby radzenia sobie ze stresem u chorych na cukrzycę typu 2 [Disease acceptation and ways of coping with the emotional stress of diabetes type 2]. Diabetol Prakt. 2011;12(3):113-119. Polish.

32. Lewko J, Polityńska B, Kochanowicz J, et al. Quality of life and its relationship to the degree of illness acceptance in patients with diabetes and peripheral diabetic neuropathy. Adv Med Sci. 2007; 52(supp11):144-146.

33. Basińska MA, Zalewska-Rydzkowska D, Wolańska P, Junik R. Dyspozycyjny optymizm a akceptacja choroby w grupie osób z chorobą Gravesa-Basedowa [Dispositional optimism and acceptance of illness among a group of individuals with Graves-Basedow's disease]. Endokrynol Pol. 2008;59(1):23-28. Polish.

34. Kurpas D, Czech T, Mroczek B. Akceptacja choroby pacjentów z cukrzycą oraz jej wpływ na jakość życia i subiektywną ocenę zdrowia [Illness acceptance in patients with diabetes and its influence on the quality of life and the subjective assessment of health]. Fam Med Primary Care Rev. 2012;14(3):383-388. Polish.

35. Łatka J, Majda A, Sołtys A. Akceptacja choroby przez chorych hemodializowanych [Determinants of acceptance of the illness by hemodialysis patients]. Nurs Top. 2013;21(3):318-326. Polish.

36. Kurowska K, Kasprzyk A. Akceptacja choroby i style radzenia sobie ze stresem u osób dializowanych [Disease acceptance and the ways of coping with stress inpatients on dialysis]. Psychiatr Psychol Klin. 2013;13(2):99-107. Polish and English.

37. Basińska MA, Waraksa-Wiśniewska M. Andruszkiewicz. Nastrój jako wyznacznik akceptacji choroby pacjentów dializowanych [Mood as acceptance of illness determinant of dialysis patients]. Nefrologia $i$ Dializoterapia Polska. 2014;18(1):27-31. Polish.

38. Kupcewicz E, Abramowicz A. Wpływ wybranych czynników socjodemograficznych na stopień akceptacji choroby i poziom satysfakcji z życia u pacjentów leczonych z powodu przewlekłej obturacyjnej choroby pluc [Influence of selected socio-demographic factors on degree of illness acceptance and on level of satisfaction with life in patients with chronic obstructive pulmonary disease]. Hygeia Public Health. 2015;50(1):142-148. Polish.
39. Majda A, Józefowska H. Zasoby osobiste pacjentów z przewlekłą obturacyjną chorobą płuc [Psychological status patients with chronic obstructive pulmonary disease]. Probl Pielęg. 2009;17(4):283-293. Polish.

40. Rusin-Pawełek E, Uchmanowicz I, Jankowska-Polańska B, Panaszek B, Fal MA. Akceptacja choroby pacjentów chorych na astmę oskrzelową a kontrola astmy oskrzelowej [Acceptance of illness of patients with bronchial asthma and asthma control]. Wspótczesna alergologia. 2012;7(28):61-67. Polish

41. Adamska M, Juczyńska K, Miniszewska J. Sposób postrzegania własnej choroby jako czynnik wyznaczający jej akceptację u osób chorych na łuszczycę [Perception of the disease as determinant of illness acceptance in patients with psoriasis]. Curr Probl Psychiatry. 2015;16(1):26-37. Polish.

42. Pawlik M, Karczmarek-Borowska B. Akceptacja choroby nowotworowej u kobiet po mastektomii [Acceptance of cancer in women after mastectomy]. Prz Med Uniw Rzesz Inst Leków. 2013;2:203-211. Polish.

43. Lelonek B, Kaczmarczyk M. Przystosowanie do choroby u pacjentów leczonych na oddziale chirurgicznym [Adjustment to illness in patients treated in the surgery ward]. Stud Med. 2011;24:45-52. Polish.

44. Niedzielski A, Humeniuk E, Błaziak P, Fedoruk E. Stopień akceptacji choroby w wybranych chorobach przewlekłych [The degree of disease acceptance in selected chronic disease]. Wiad Lek. 2007;60(5-6): 224-227. Polish.

45. Moczydłowska A, Krajewska-Kuła E, Kózka M, Bielski K. Stopień akceptacji choroby przez pacjentów oddziałów zachowawczych i zabiegowych [The degree of disease acceptance by patients from nonsurgical and surgical wards]. Pielęgniarstwo Chirurgiczne i Angiologiczne. 2014;2:62-70. Polish.

46. Czyżewska P, Makarowicz S, Talarska D, Stanisławska J, DrozdGajdus E, Strugała M. Poczucie wsparcia społecznego u osób chorych na padaczkę [The feeling of social support in people with epilepsy] Pielęg Pol. 2014;2(52):106-110. Polish.

47. Karna-Matyjaszek U, Sierżantowicz R, Mariak Z. Akceptacja własnej choroby przez pacjentów z rozpoznaną jaskrą [Acceptance of own disease by patients with diagnosed glaucoma]. Pol Merk Lek. 2010; 163:37. Polish

48. Jóźwiak S. One są wśród nas. Dziecko z padaczką w szkole i przedszkolu. Informacje dla pedagogówi opiekunów. Warszawa: Ministerstwo Edukacji Narodowej; 2009.

49. Jędrzejczak J. Jak żyć z padaczką? Poradnik dla chorych i ich rodzin. Warszawa: Novartis; 2006.

50. Visée $H$. The relationship between alcohol and seizures: an overview of the major, data. Int J Neurorehabil Eng. 2015;2(141):1-4.

51. Alldredge BK, Lowenstein DH. Status epilepticus related to alcohol abuse. Epilepsia. 1993;34:1033-1037.

52. Lowenstein DH, Alldredge BK. Status epilepticus at an urban public hospital in the 1980s. Neurology. 1993;43:483-488.

53. Aminoff MJ, Simon RP. Status epilepticus: causes, clinical features and consequences in 98 patients. Am J Med. 1980;69:657-666.

54. Koncewicz R. Drgawki - problem w podstawowej opiece zdrowotnej [Seizures - a problem in basic health care]. Med Rodzinna. 2002 5:179-182. Polish.

55. Gopinath B, Radhakrishnan K, Sankara PS, Jayachandran D, Alexander A. A questionnaire survey about doctor-patient communication, compliance and locus of control among South Indian people with epilepsy. Epilepsy Res. 2000;39:73-82.

56. Baker GA. The psychosocial burden of epilepsy. Epilepsia. 2002; 43(6):26-30.

57. Niedzielska K, Wolańczyk T, Baker GA, Jakoby A, Doughty J, De Boer H Program Sanofi-Synthelabo dotyczący wiedzy na temat padaczki europejskie badanie chorych na padaczkę i ich opiekunów - wyniki polskie [Level of knowledge about epilepsy among Polish patients with epilepsy and their families in the European study SPOKE (SanofiSynthelabo Programme for Outcome Knowledge of Epilepsy)]. Neurol Neurochir Pol. 2004;38(6):447-455. Polish. 
Patient Preference and Adherence

Dovepress

\section{Publish your work in this journal}

Patient Preference and Adherence is an international, peer-reviewed, open access journal that focuses on the growing importance of patient preference and adherence throughout the therapeutic continuum. Patient satisfaction, acceptability, quality of life, compliance, persistence and their role in developing new therapeutic modalities and compounds to optimize

clinical outcomes for existing disease states are major areas of interest for the journal. This journal has been accepted for indexing on PubMed Central. The manuscript management system is completely online and includes a very quick and fair peer-review system, which is all easy to use. Visit http://www. dovepress.com/testimonials.php to read real quotes from published authors.

Submit your manuscript here: http://www.dovepress.com/patient-preference-and-adherence-journal 